\title{
Impact of the ocean carbonate chemistry on living foraminiferal shell weight: Comment on "Carbonate ion concentration in glacial-age deep waters of the Caribbean Sea" by W. S. Broecker and E. Clark
}

\author{
Jelle Bijma, Bärbel Hönisch, and Richard E. Zeebe \\ Alfred Wegener Institute, Am Handelshafen 12, Bremerhaven, D-27570, Germany \\ (jbijma@awi-bremerhaven.de; bhoenisch@awi-bremerbaven.de; rzeebe@awi-bremerhaven.de)
}

Components: 3500 words, 2 figures.

Keywords: Comment; planktonic; foraminifera; dissolution; carbonate; chemistry.

Index Terms: 1050 Geochemistry: Marine geochemistry (4835, 4850); 4267 Oceanography: General: Paleoceanography; 3030 Marine Geology and Geophysics: Micropaleontology.

Received 5 June 2002; Revised 23 July 2002; Accepted 23 July 2002; Published 8 November 2002.

Bijma, J., B. Hönisch, and R. E. Zeebe, The impact of the ocean carbonate chemistry on living foraminiferal shell weight: Comment on "Carbonate ion concentration in glacial-age deep waters of the Carribbean Sea" by W. S. Broecker and E. Clark, Geochem. Geophys. Geosyst., 3(11), 1064, doi:10.1029/2002GC000388, 2002.

\section{Introduction}

[1] Broecker and Clark [2002] use the "size normalized weight" of planktic foraminifera to estimate the carbonate ion concentration $\left(\left[\mathrm{CO}_{3}^{\overline{-}}\right]\right)$ of Atlantic glacial upper deep water. This method was introduced by Lohmann [1995] and is based on the fact that, within a defined size fraction, dissolution decreases shell weight in proportion to the degree of undersaturation with respect to $\mathrm{CaCO}_{3}$. On the basis of the following assumptions: (1) the thickness of the foraminiferal shell wall does not depend on growth conditions, (2) the saturation $\left[\mathrm{CO}_{3}^{=}\right]$for calcite, $\left[\mathrm{CO}_{3}^{=}\right]_{\text {sat. }}$, increases by $20 \mu \mathrm{mol} \mathrm{kg} \mathrm{km}^{-1}$ [Broecker and Clark, 2001], (3) the weight loss slope is universal and ca. $\left.0.3 \mu \mathrm{g}(\mu \mathrm{mol} \mathrm{kg})^{-1}\right)^{-1}$ [Broecker and Clark, 2001], and (4) the offset between the bottom water and pore water $\left[\mathrm{CO}_{3}^{\overline{ }}\right]$ was the same during glacial time as during the Holocene, Broecker and Clark [2002] calculate that the $\left[\mathrm{CO}_{3}^{-}\right]$of Atlantic glacial upper deep water was $14 \mu \mathrm{mol} \mathrm{kg}{ }^{-1}$ higher than during the Holocene. Although they recognize that some of their assumptions are not strictly valid, they do not assess the impact of those assumptions on their $\left[\mathrm{CO}_{3}^{\overline{ }}\right]$ estimate. Here we comment on several of those assumptions and attempt to quantify their impact on Broecker and Clark's [2002] calculations.

\section{Assumption 1}

[2] Broecker and Clark [2002] provide evidence that this assumption is not valid. At the same pressure-normalized $\left[\mathrm{CO}_{3}^{\overline{ }}\right]$, P. obliquiloculata from the Pacific Ocean is consistently $10 \mu \mathrm{g}$ heavier than those from the Indian Ocean. Spero and Lea [1993] have shown that G. sacculifer cultured under high light intensities grows bigger and is more massive than under lower light conditions. Hemleben et al. [1987] have demonstrated that G. sacculifer cultured 
at higher temperatures grows larger. Unfortunately they did not measure shell weight. Chamber number/ size/weight relationships for the symbiont barren species G. bulloides differ from location to location [Spero and Lea, 1996]. For instance, comparable ontogenetic stages from the Chatham Rise are bigger and heavier than those from the San Pedro Basin. Apparently, besides potential genetic differences [e.g., Darling et al., 1999, 2000; Huber et al., 1997], growth conditions affect the size normalized weight.

[3] Broecker and Clark [2002] point out that temperature and $\left[\mathrm{CO}_{3}^{\overline{ }}\right]$ are likely candidates. Elderfield (personal communication, 2001) showed that shell wall thickness is closely related to growth temperature. On the other hand, Bijma et al. [1999] demonstrated that shell weight of $O$. universa is primarily a function of the $\left[\mathrm{CO}_{3}^{\overline{-}}\right]$ of the ambient water (Figure 1a). It can be demonstrated that $\left[\mathrm{CO}_{3}^{\overline{ }}\right]$ primarily affects shell thickness and that shell weight is a derived parameter of that relationship. For reasons of comparability and simplicity we use the $\left[\mathrm{CO}_{3}^{\bar{\Xi}}\right]$-weight relationship here.

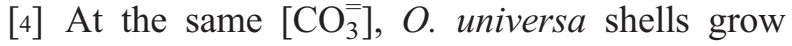
heavier under high light than under low light conditions. Apparently, the $\left[\mathrm{CO}_{3}^{-}\right]$at the site of calcification (SOC) reflects the ambient $\left[\mathrm{CO}_{3}^{=}\right]$but is modified by physiological processes (respiration, calcification, and photosynthesis) of the foraminifer and its symbionts [Wolf-Gladrow et al., 1999]. Broecker and Clark [2002] point out that in today's ocean a very tight correlation exists between surface water $\left[\mathrm{CO}_{3}^{=}\right]$and temperature and that core top shell weights can thus not be used to distinguish between a temperature or a carbonate ion dependence (in equilibrium with today's atmosphere, the temperature impact on $\left[\mathrm{CO}_{3}^{-}\right]$varies roughly between 5 and $6 \mu \mathrm{mol} \mathrm{kg} \mathrm{kg}^{-1} \mathrm{~K}^{-1}$ for surface alkalinities between 2100 and $2400 \mu \mathrm{mol} \mathrm{kg}{ }^{-1}$, respectively).

[5] Barker and Elderfield [2002] have adopted an approach where they follow the evolution of shell weight through time and compare this to predictions made from carbon system modeling. They demonstrate that shell weight of $G$. bulloides decreases from the last termination toward the
Holocene. This trend suggests that $\left[\mathrm{CO}_{3}^{\overline{ }}\right]$ controls weight rather than temperature since $\left[\mathrm{CO}_{3}^{=}\right]$ decreases while temperature increases during the deglaciation. This finding is corroborated by laboratory experiments. We have evidence, albeit less well constrained than for $O$. universa, that shell weight of $G$. sacculifer depends on the carbonate chemistry of the ambient water (Figure 1b), and there is a priori no reason to assume that this phenomenon is restricted to these two species or to foraminifera in general. A similar impact of the carbonate chemistry has been demonstrated for corals [Gattuso and Buddemeier, 2000; Gattuso et al., 1998; Kleypas et al., 1999] and for coccolithophorids [Riebesell et al., 2000; Zondervan et al., 2001]. The experimental results suggest that shell weight of individual $G$. sacculifer increases by $3 \mu \mathrm{g}$ for every $100 \mu \mathrm{mol} \mathrm{kg}{ }^{-1}$ increase in $\left[\mathrm{CO}_{3}^{=}\right]$. It should be noted that only a part of the life cycle has been spent under controlled laboratory conditions and hence that the real slope may be steeper. The point of the matter is that growth differences have to be considered, not only between species and in space but in time as well.

[6] If we accept Sanyal et al.'s [1995] glacial surface water $\mathrm{pH}$ reconstruction, which is in agreement with the ice core $\mathrm{pCO}_{2}$ measurements, and assume that the sites investigated by Broecker and Clark [2002] were in equilibrium with the atmosphere, the glacial $\left[\mathrm{CO}_{3}^{\overline{-}}\right]$ must have been significantly higher. Depending on which scenario is followed to achieve glacial $\mathrm{pCO}_{2}$ values, $\mathrm{CO}_{2}$ extraction or $\mathrm{CaCO}_{3}$ addition, the tropical glacial surface ocean $\left[\mathrm{CO}_{3}^{=}\right]$ was 50 to $120 \mu \mathrm{mol} \mathrm{kg}{ }^{-1}$ higher, respectively, compared with the Holocene [Lea et al., 1999]. Hence before $G$. sacculifer settled to the ocean floor, glacial specimens must have been heavier in weight than their Holocene counterparts from the same site. Using our empirical relationship, 1.5 to $3.6 \mu \mathrm{g}$ of the glacial weight increase in G. sacculifer was due to the fact that shells grew heavier. On the basis of a glacial-interglacial temperature difference for tropical surface waters of $3^{\circ} \mathrm{C}$, an average slope of $\left[\mathrm{CO}_{3}^{=}\right]$versus temperature of $5.5 \mu \mathrm{mol} \mathrm{kg}{ }^{-1} \mathrm{~K}^{-1}$, and an experimental slope of $3 \mu \mathrm{g}$ weight increase for every $100 \mu \mathrm{mol} \mathrm{kg}{ }^{-1}$ increase in $\left[\mathrm{CO}_{3}^{\overline{ }}\right]$, the impact on shell weight of temperature alone is 


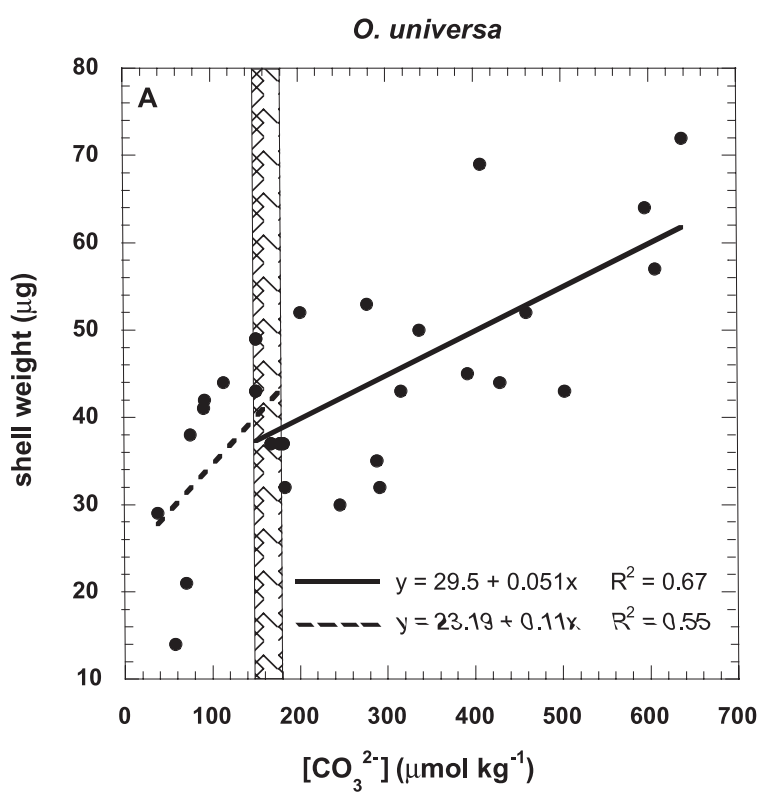

G. sacculifer

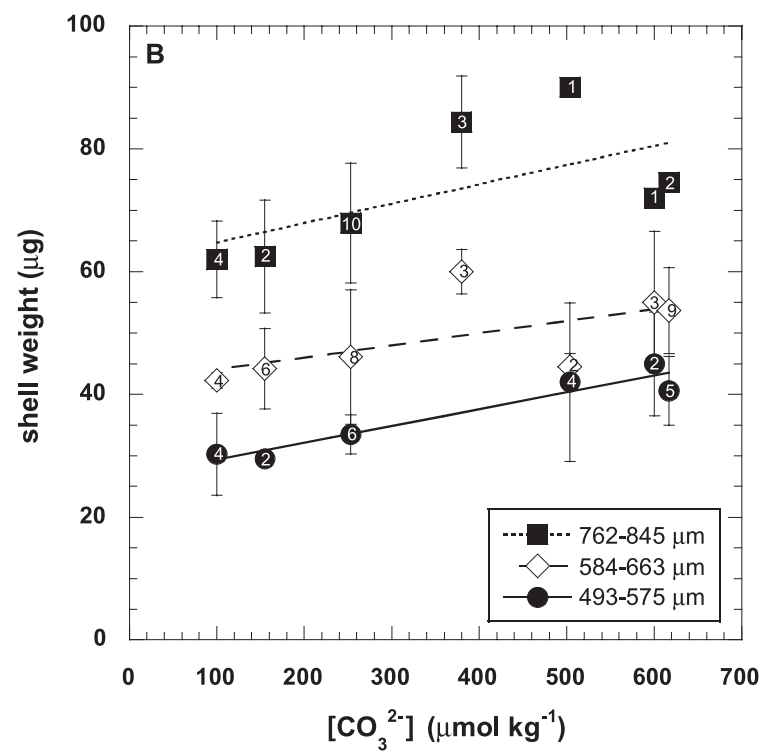

$<0.5 \mu \mathrm{g}$. Hence the effective glacial-Holocene weight difference decreases. It is reasonable to assume that the change in the glacial surface $\left[\mathrm{CO}_{3}^{\bar{y}}\right]$ was brought about by a combination of both scenarios. Assuming that the average weight of glacial $G$. sacculifer was $2.6 \mu \mathrm{g}$ heavier, the glacial-interglacial weight difference for this species reduces from 4.9 to $2.3 \mu \mathrm{g}$. Consequently, using the $\left.0.3 \mu \mathrm{g}(\mu \mathrm{mol} \mathrm{kg})^{-1}\right)^{-1}$ calibration of Broecker and Clark [2002], the glacial $\left[\mathrm{CO}_{3}^{=}\right]$increase reduces from $14 \mu \mathrm{mol} \mathrm{kg} \mathrm{kg}^{-1}$ to $8 \mu \mathrm{mol} \mathrm{kg} \mathrm{kg}^{-1}$.

\section{Assumption 2}

[7] Although the true relationship between pressure and $\left[\mathrm{CO}_{3}^{=}\right]_{\text {sat. }}$ is exponential, a linear approximation

Figure 1. (opposite) Planktonic foraminifera were grown in the laboratory in a 12 hour light/dark cycle under a range of $\left[\mathrm{CO}_{3}^{=}\right]$until gametogenesis (for details see Bijma et al., 1999). Empty shells were dried, measured, and weighed individually. (a) Individual $O$. universa shell weights of the size fraction 500-600 $\mu \mathrm{m}$ plotted as a function of $\left[\mathrm{CO}_{3}^{=}\right]$. The shaded area represents the range of ambient $\left[\mathrm{CO}_{3}^{=}\right]$. The data from several experiments (constant alkalinity, constant $\mathrm{\Sigma CO}_{2}$, and constant $\mathrm{pH}$ ) are combined [Bijma et al., 1999]. Linear regressions were fitted to data below and above ambient $\left[\mathrm{CO}_{3}^{\bar{z}}\right]$. (b) Globigerinoides sacculifer was only grown at constant $\Sigma \mathrm{CO}_{2}$. Average shell weights of three different size ranges (closed circles: 493-575 $\mu \mathrm{m}$; open diamonds: 584-663 $\mu \mathrm{m}$; closed squares: 762-845 $\mu \mathrm{m}$ ). Numbers in the symbols indicate the number of specimens for each data point. Statistical analysis based on the individual data points shows that the slopes are significant at the $90 \%, 95 \%$, and $95 \%$ confidence level, respectively for the size intervals $493-575 \mu \mathrm{m}, 584-$ $663 \mu \mathrm{m}$, and 762-845 $\mu \mathrm{m}$. Regression analysis yields slopes of $2.5,2.1$, and $3.6 \mu \mathrm{g}$ per $100 \mu \mathrm{mol} \mathrm{kg} \mathrm{kg}^{-1}$, demonstrating that ontogeny has little effect on the relationship:

$493-575 \mu \mathrm{m}: \operatorname{Wgt}(\mu \mathrm{g})=27.3+0.025 \cdot\left[\mathrm{CO}_{3}^{=}\right]\left(\mathrm{r}^{2}=0.39\right)$

$584-663 \mu \mathrm{m}: \operatorname{Wgt}(\mu \mathrm{g})=41.4+0.021 \cdot\left[\mathrm{CO}_{3}^{=}\right] \quad\left(\mathrm{r}^{2}=0.22\right)$

$762-845 \mu \mathrm{m}: \operatorname{Wgt}(\mu \mathrm{g})=59.8+0.036 \cdot\left[\mathrm{CO}_{3}^{=}\right]\left(\mathrm{r}^{2}=0.28\right)$

The sieve size range used by Broecker and Clark [2001, 2002] (350-415 $\mu \mathrm{m})$ can be converted to a real shell size range of $493-575 \mu \mathrm{m}$ by using the growth curve for G. sacculifer provided by Hemleben and Bijma [1994]. In other words, the shell weight of $G$. sacculifer increases ca. $3 \mu \mathrm{g}$ for every $100 \mu \mathrm{mol} \mathrm{kg} \mathrm{kg}^{-1}$ increase in $\left[\mathrm{CO}_{3}^{=}\right]$. 
for the depth range between 3 and $4 \mathrm{~km}$ water depth is quite acceptable. However, the coefficient of 20 $\mu \mathrm{mol} \mathrm{kg} \mathrm{kg}^{-1} \mathrm{~km}^{-1}$ [Ingle, 1975] used by Broecker and Clark [2002] is the largest among a range of values. For instance, on the basis of the relationship $\left[\mathrm{CO}_{3}^{=}\right]_{\text {sat. }}=90 \cdot \mathrm{e}^{(0.16 \cdot(\mathrm{z}-4))}$ [Broecker and Takahashi, 1978] the change in the saturation $\left[\mathrm{CO}_{3}^{\overline{ }}\right]$ between 3 and $4 \mathrm{~km}$ depth equals $13 \mu \mathrm{mol} \mathrm{kg}{ }^{-1} \mathrm{~km}^{-1}$. Using the parameterization of Millero [1995], the saturation $\left[\mathrm{CO}_{3}^{=}\right]$increases by $16 \mu \mathrm{mol} \mathrm{kg}{ }^{-1}$ between 3 and $4 \mathrm{~km}$ depth. Although Broecker and Clark [2002] acknowledge that the true slope may be in the range of $15 \pm 2 \mu \mathrm{mol} \mathrm{kg}^{-1} \mathrm{~km}^{-1}$, they choose to use $20 \mu \mathrm{mol} \mathrm{kg}{ }^{-1} \mathrm{~km}^{-1}$. Jansen et al. [2002] fitted the (more convenient) equation of Broecker and Takahashi $[1978]$ to the critical $\left[\mathrm{CO}_{3}^{=}\right]$as calculated by Millero [1995]. Using this approximation $\left(\left[\mathrm{CO}_{3}^{\overline{ }}\right]_{\text {sat. }}=88.7 \cdot \mathrm{e}^{(0.189 \cdot(\mathrm{z}-3.82))}\right)$, the slope for the depth range between 3 to $4 \mathrm{~km}$ is $16 \mu \mathrm{mol} \mathrm{kg} \mathrm{kg}^{-1}$ $\mathrm{km}^{-1}$. A smaller pressure impact tends to increase the weight loss slope and hence reduces the glacial $\left[\mathrm{CO}_{3}^{\overline{ }}\right]$ estimate even more.

\section{Assumption 3}

[8] Berger [1968] and Parker and Berger [1971] and many others after that demonstrated that planktic foraminifera are differently susceptible to dissolution. Hence one could argue that the critical $\left[\mathrm{CO}_{3}\right]$ is slightly different for each species and that therefore the weight loss slopes must be species dependent and not universal. The fact that G. ruber does not show the glacial-Holocene weight difference as the other species studied by Broecker and Clark [2002] bolsters this contention. To verify the assumption that weight loss slopes are species dependent, we have replotted shell weights from Table 1 in Broecker and Clark [2001] against the pressure corrected $\left[\mathrm{CO}_{3}^{=}\right]$(Figure 2). On the basis of the $20 \mu \mathrm{mol} \mathrm{kg} \mathrm{km}^{-1}$ change in $\left[\mathrm{CO}_{3}^{=}\right]_{\text {sat. }}$ used by Broecker and Clark [2001] the slopes of the linear regressions are $0.46,0.57$, and $0.68 \mu \mathrm{g}(\mu \mathrm{mol}$ $\left.\mathrm{kg}^{-1}\right)^{-1}$ for G. sacculifer, P. obliquiloculata, and $N$. dutertrei, respectively. Using the smaller pressure effect on $\left[\mathrm{CO}_{3}^{=}\right]_{\text {sat. }}$ of Jansen et al. [2002], the slopes amend to $0.45,0.66$, and $0.65 \mu \mathrm{g}$ ( $\mu \mathrm{mol}$ $\left.\mathrm{kg}^{-1}\right)^{-1}$, respectively (Figure 2). Note that the inconsistency between the weight loss slopes and
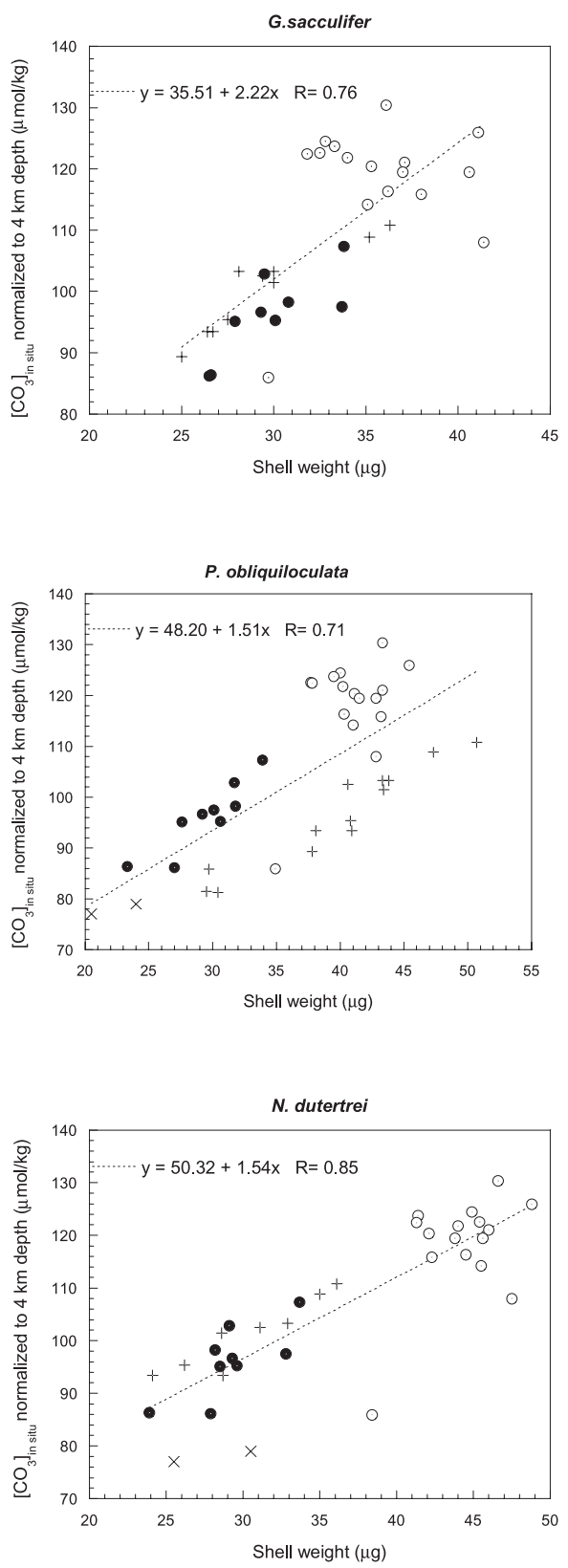

Figure 2. Plots of whole shell weights (size range $355-415 \mu \mathrm{m})$ as determined by Broecker and Clark [2002] versus the pressure corrected $\left[\mathrm{CO}_{3}^{=}\right],\left[\mathrm{CO}_{3}^{=}\right]^{*}=$ $\left[\mathrm{CO}_{3}^{=}\right]_{\text {in situ }}+\Delta\left[\mathrm{CO}_{3}^{=}\right]_{(4-\mathrm{z})}$, where $\Delta\left[\mathrm{CO}_{3}^{=}\right]_{(4-\mathrm{z})}$ is the difference in $\left[\mathrm{CO}_{3}^{=}\right]$between the water depth at the core site and $4 \mathrm{~km}$ and $\left[\mathrm{CO}_{3}^{=}\right]_{\text {at } 4 \mathrm{~km} \text { depth }}$ is calculated after Millero [1995]. Open circles represent Atlantic data, closed circles are from the Indian Ocean, and crosses $(+)$ and $x$ are from the western and eastern Pacific, respectively. 
the ranking to dissolution provided by Parker and Berger [1971] is most likely due to the combined effect of susceptibility to dissolution and wall thickness (i.e., the initial shell weight). Assuming an average slope of $\left.0.5 \mu \mathrm{g}(\mu \mathrm{mol} \mathrm{kg})^{-1}\right)^{-1}$, the estimated $\left[\mathrm{CO}_{3}^{=}\right]$increase of glacial Atlantic upper deep water, as calculated by Broecker and Clark [2001], decreases by $43 \%$ from 14 to $8 \mu \mathrm{mol} \mathrm{kg}{ }^{-1}$. However, as argued above, the slopes are species specific, and $\Delta\left[\mathrm{CO}_{3}^{=}\right]$should therefore be calculated on a per species basis. For the Caribbean cores the glacial-Holocene increase in $\left[\mathrm{CO}_{3}^{\overline{ }}\right]$ is then estimated to be 11 and $5 \mu \mathrm{mol} \mathrm{kg}{ }^{-1}$ on the basis of G. sacculifer and N. dutertrei, respectively. Apparently, the critical $\left[\mathrm{CO}_{3}^{=}\right]$for G. sacculifer is higher than that for $N$. dutertrei (i.e., at the same water depth, the Holocene-glacial weight difference for $G$. sacculifer is larger than for $N$. dutertrei). The average of the two species is, of course, $8 \mu \mathrm{mol}$ $\mathrm{kg}^{-1}$, but the question arises which of the two species provides the best estimate? Combining the impact of a steeper weight loss slope for $G$. sacculifer with that of higher glacial surface water $\left[\mathrm{CO}_{3}^{=}\right]$on $\mathrm{G}$. sacculifer shell weight reduces the glacial $\left[\mathrm{CO}_{3}^{=}\right]$increase estimate to $5 \mu \mathrm{mol} \mathrm{kg}{ }^{-1}$.

\section{Assumption 4}

[9] In addition to the assumption that the difference between the bottom and pore water $\left[\mathrm{CO}_{3}^{\overline{ }}\right]$ was the same during glacial time as during the Holocene, Broecker and Clark [2001] assume that the offset between bottom and pore water $\left[\mathrm{CO}_{3}\right]$ is constant with depth and between different sites. However, because the rain ratio (carbonate carbon/organic carbon) changes with depth and differs from location to location, these assumptions may not be valid. In fact, Broecker and Clark [2001] note that the observed correlation between the weights of $G$. sacculifer, P. obliquiloculata, and N. dutertrei for the core top samples from the Ceara Rise demon-

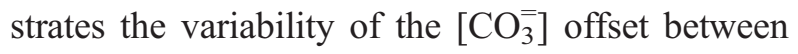
bottom and pore water.

[10] Because of nonlinear dissolution kinetics, the offset between bottom and pore water $\left[\mathrm{CO}_{3}^{=}\right]$ changes drastically from above to below the saturation horizon $(\mathrm{SH})$. Above the $\mathrm{SH}$, pore water is less saturated with respect to calcite than bottom water (because of respiration-driven pore water dissolution). Bottom water $\left[\mathrm{CO}_{3}^{=}\right]$reaches the critical value at the $\mathrm{SH}$; "interface" dissolution starts and progresses exponentially toward greater depths. Because the dissolution kinetics are not infinitely fast, an offset is created between the SH and the lysocline. In this depth interval, called the transition zone, the saturation state of the pore water increases from less saturated to more saturated than the bottom water. Note that there is a depth where the $\left[\mathrm{CO}_{3}^{\overline{ }}\right]$ of bottom and pore water converge. This demonstrates that the offset between bottom and pore water is not constant with depth and hence that the slope of the weight loss per unit change in $\left[\mathrm{CO}_{3}^{=}\right]$changes below the $\mathrm{SH}$. Consequently, the size-normalized weight method should probably be restricted to cores that have never seen in situ bottom water $\left[\mathrm{CO}_{3}^{=}\right]$below the critical $\left[\mathrm{CO}_{3}^{\bar{E}}\right]$.

[11] One could argue that the variability in the $\left[\mathrm{CO}_{3}^{\bar{y}}\right]$ offset between bottom and pore water is a fatal blow for Lohmann's method. However, we should keep in mind that we are dealing with a proxy and that such complications are to be expected. They basically set the limit for the accuracy of the method. A better understanding of the $\left[\mathrm{CO}_{3}^{\bar{*}}\right]$ variations between bottom and pore water is needed to improve the robustness of the method.

[12] Above the saturation horizon the range of $\mathrm{pH}$ offsets between bottom and pore water, for instance at the Ontong-Java Plateau, is somewhere between 0.02 and $0.04 \mathrm{pH}$ units [Hales and Emerson, 1996]. This translates roughly to a $\left[\mathrm{CO}_{3}^{\overline{ }}\right]$ offset between 5 and $10 \mu \mathrm{mol} \mathrm{kg} \mathrm{kg}^{-1}$. Using the average weight loss slope of $\left.0.5 \mu \mathrm{g}(\mu \mathrm{mol} \mathrm{kg})^{-1}\right)^{-1}$, this implies that weight differences between 2.5 and $5 \mu \mathrm{g}$ are within the uncertainty for reconstructing bottom water $\left[\mathrm{CO}_{3}^{\overline{\bar{N}}}\right]$.

[13] The restriction to cores that have never bathed in waters below the critical $\left[\mathrm{CO}_{3}^{=}\right]$has also been noted by Broecker and Clark [2002]. In addition, they argue that data from shallow cores bathing in water with a $\left[\mathrm{CO}_{3}^{=}\right]$higher than $120 \mu \mathrm{mol} \mathrm{kg}{ }^{-1}$ should be omitted (because the reduction in $\left[\mathrm{CO}_{3}^{\overline{ }}\right]$ 
resulting from the release of respiration $\mathrm{CO}_{2}$ in the pore water is more than compensated by the excess of bottom water $\left[\mathrm{CO}_{3}^{=}\right]$over calcite saturation).

[14] Some of the cores used by Broecker and Clark [2001] to determine the weight loss slopes are from below the SH (based on Jansen et al., 2002) or from in situ $\left[\mathrm{CO}_{3}^{\bar{E}}\right]$ higher than $120 \mu \mathrm{mol} \mathrm{kg}{ }^{-1}$. Limiting their data to $\left[\mathrm{CO}_{3}^{\overline{ }}\right]_{\text {sat. }}<\left[\mathrm{CO}_{3}^{\overline{ }}\right]_{\text {in situ }}<120$, the weight loss slopes for $G$. sacculifer and $N$. dutertrei become 0.62 and $\left.0.93 \mu \mathrm{g}(\mu \mathrm{mol} \mathrm{kg})^{-1}\right)^{-1}$, respectively. The estimated glacial increase in $\left[\mathrm{CO}_{3}\right]$ for the Caribbean cores now decreases to 8 and $4 \mu \mathrm{mol} \mathrm{kg} \mathrm{kg}^{-1}$ on the basis of G. sacculifer and $N$. dutertrei, respectively.

[15] If we combine the new estimate of the weight loss slope for $G$. sacculifer with the impact of higher glacial surface water $\left[\mathrm{CO}_{3}^{\overline{-}}\right]$ on this species, the $\Delta\left[\mathrm{CO}_{3}^{=}\right]$estimate based on $G$. sacculifer reduces to $4 \mu \mathrm{mol} \mathrm{kg}{ }^{-1}$. This brings the predicted average increase in $\left[\mathrm{CO}_{3}^{=}\right]$of Atlantic glacial upper deep water based on $G$. sacculifer (including the impact of higher glacial surface water $\left[\mathrm{CO}_{3}^{\overline{ }}\right]$ on initial shell weight) close to the prediction of $4 \mu \mathrm{mol} \mathrm{kg} \mathrm{kg}^{-1}$ based on $N$. dutertrei (without an impact of higher glacial surface water $\left[\mathrm{CO}_{3}^{=}\right]$on initial shell weight). This could suggest that during growth the shell weight of $N$. dutertrei does not respond strongly to the $\left[\mathrm{CO}_{3}^{\overline{-}}\right]$, if at all. However, the predicted increase in $\left[\mathrm{CO}_{3}^{-}\right]$of $4 \mu \mathrm{mol} \mathrm{kg}^{-1}$ for Atlantic glacial upper deep water is within the range of uncertainty related to the variability in the $\left[\mathrm{CO}_{3}^{=}\right]$offset between bottom and pore water, leaving the question open for further debate.

\section{Acknowledgments}

[16] We would like to thank Howard J. Spero and David W. Lea for comments on earlier versions of the manuscript and for many years of intensive collaboration in the laboratory in which the shell weight measurements were generated.

\section{References}

Barker, S., and H. Elderfield, Foraminiferal calcification response to glacial-interglacial changes in atmospheric $\mathrm{CO}_{2}$, Science, 297, 833-836, 2002.

Berger, W. H., Planktonic foraminifera: Selective solution and paleoclimatic interpretation, Deep Sea Res., 15(1), 31-43, 1968.
Bijma, J., H. J. Spero, and D. W. Lea, Reassessing foraminiferal stable isotope geochemistry: Impact of the oceanic carbonate system (experimental results), in Use of Proxies in Paleoceanography: Examples from the South Atlantic, edited by G. Fischer and G. Wefer, pp. 489-512, Springer-Verlag, New York, 1999.

Broecker, W., and E. Clark, An evaluation of Lohmann's foraminifera weight dissolution index, Paleoceanography, 16(5), 531-534, 2001.

Broecker, W., and E. Clark, Carbonate ion concentration in glacial-age deep waters of the Caribbean Sea, Geochem. Geophys. Geosys., 2002.

Broecker, W. S., and T. Takahashi, The relationship between lysocline depth and in situ carbonate ion concentration, Deep Sea Res., 25, 65-95, 1978.

Darling, K. F., C. M. Wade, D. Kroon, A. J. L. Brown, and J. Bijma, The diversity and distribution of modern planktic foraminiferal small subunit ribosomal RNA genotypes and their potential as tracers of present and past ocean circulation, Paleoceanography, 14(1), 3-12, 1999.

Darling, K. F., et al., Molecular evidence for genetic mixing of Artic and Antarctic subpolar populations of planktonic foraminifers, Nature, 405, 43-47, 2000.

Gattuso, J.-P., and R. W. Buddemeier, Calcification and $\mathrm{CO}_{2}$, Nature, 407, 311-313, 2000.

Gattuso, J.-P., M. Frankignoulle, I. Bourge, S. Romaine, and R. W. Buddemeier, Effect of calcium carbonate saturation of seawater on coral calcification, Global Planet. Change, 18(1-2), 37-46, 1998.

Hales, B., and S. Emerson, Calcite dissolution in sediments of the Ontong-Java Plateau: In situ measurements of pore water $\mathrm{O}_{2}$ and $\mathrm{pH}$, Global Biogeochem. Cycles, 10(3), 527-541, 1996.

Hemleben, C., and J. Bijma, Foraminiferal population dynamics and stable carbon isotopes, in Carbon Cycling in the Glacial Ocean: Constraints on the Oceańs Role in Global Change, pp. 145-166, edited by R. Zahn, et al., NATO ASI, Elsevier Sci., New York, 1994.

Hemleben, C., M. Spindler, I. Breitinger, and R. Ott, Morphological and physiological responses of Globigerinoides sacculifer (Brady) under varying laboratory conditions, Mar. Micropaleontol., 12(4), 305-324, 1987.

Huber, B. T., J. Bijma, and K. Darling, Cryptic speciation in the living planktonic foraminifer Globigerinella siphonifera (d'Orbigny), Paleobiology, 23(1), 33-62, 1997.

Ingle, S. E., Solubility of calcite in the ocean, Marine Chem., 3, 301-319, 1975.

Jansen, H., R. E. Zeebe, and D. A. Wolf-Gladrow, Modeling the dissolution of settling $\mathrm{CaCO}_{3}$ in the ocean, Global Biogeochem. Cycles, 16(2), 1027, doi:10.1029/2000GB001279, 2002.

Kleypas, J. A., et al., Geochemical consequences of increased atmospheric carbon dioxide on coral reefs, Science, 284 , $118-120,1999$.

Lea, D. W., J. Bijma, H. J. Spero, and D. Archer, Implications of a carbonate ion effect on shell carbon and oxygen isotopes for glacial ocean conditions, in Use of Proxies in Paleoceanography: Examples from the South Atlantic, pp. 513-522, 
edited by G. Fischer and G. Wefer, Springer-Verlag, New York, 1999.

Lohmann, G. P., A model for variation in the chemistry of planktonic foraminifera due to secondary calcification and selective dissolution, Paleoceanography, 10(3), 445-457, 1995.

Millero, F. J., Thermodynamics of the carbon dioxide system in the oceans, Geochim. Cosmochim. Acta, 59(4), 661-677, 1995.

Parker, F. L., and W. H. Berger, Faunal and solution patterns of planktonic foraminifera in surface sediments of the south pacific, Deep Sea Res., 18(1), 73-107, 1971.

Riebesell, U., et al., Reduced calcification of marine plankton in response to increased atmospheric $\mathrm{CO}_{2}$, Nature, 407(6802), 364-367, 2000.

Sanyal, A., N. G. Hemming, G. N. Hanson, and W. S. Broecker, Evidence for a higher $\mathrm{pH}$ in the glacial ocean from boron isotopes in foraminifera, Nature, 373(6511), 234-236, 1995. Spero, H. J., and D. W. Lea, Intraspecific stable isotope variability in the planktic foraminifera Globigerinoides sacculifer: Results from laboratory experiments, Marine Micropaleontology, 22(3), 221-234, 1993.

Spero, H. J., and D. W. Lea, Experimental determination of stable isotope variability in Globigerina bulloides: Implications for paleoceanographic reconstructions, Marine Micropaleontology, 28(3-4), 231-246, 1996.

Wolf-Gladrow, D. A., J. Bijma, and R. E. Zeebe, Model simulation of the carbonate system in the microenvironment of symbiont bearing foraminifera, Marine Chemistry, 64, 181198, 1999.

Zondervan, I., R. E. Zeebe, B. Rost, and U. Riebesell, Decreasing marine biogenic calcification: A negative feedback on rising atmospheric pCO2, Global Biogeochemical Cycles, 15(2), 507-516, 2001. 